\section{Beyond the Porte de Saint-Denis: Looking inside the 10th arrondissement of Paris}

\begin{abstract}
Beyond the famous Porte de Saint-Denis, there is a "multiethnic" world, the Turks, the Kurds, the Arabs, the Indians, the Pakistanis cohabit and run their business in the same economic area. Despite the multi ethnical image, that district has a common reputation: "quartier turc". In this purpose, this paper aims to present the presence of various social groups at the 10th arrondissement of Paris, particularly those who come from Turkey. The restaurants, the barbershops, the halal butcher shops or the grocery stores, placed side by side, show the diversity of the multiple forms of their economic integration. Turkish origin individuals who live and work at the 10th district, have different backgrounds, stories and reasons to settle down in Paris. In the light of this, we argue three types of migration from Turkey: first, work migration during the late 60's; second, political refugees due to political context in the 80's; and third cultural radiance (rayonnement culturel), as a new model, which encourages the educational and cultural mobilization of high skilled individuals. Each type of migration is related to the different models of the French migration policies. In this respect, we think that the field research based on the in-depth interviews will help us to discover their "migrant" universe. Focusing on a specific neighbor, known as "quartier turc", this study attempts to analyze the migration stories, and the social, economic and political integration of those Turkish origin social groups at the 10th arrondissement of Paris.
\end{abstract}

Keywords: Turkish migration; migration policies; France; Paris; 10th Arrondissement; Faubourg SaintDenis.

\title{
Introduction
}

The Turkish immigration in France that had started with the "guest workers" treatment in 1965 was one of the steps of the Turkish immigration across Europe. Following that treatment, Turkish workers came in France, especially in the early 1970's. Before 1980 (the military coup in Turkey), a time when Kurdish people emigrated to France due to political/military crises, the family reunification treatment (regroupement familial) has played a huge role in increasing the number of Turkish immigrants. Here, we do not tend to recount all the details of Turkish immigration in France, but we want to address several issues: why some Turkish immigrants settled in Paris, more specifically in the 10th arrondissement, what their

\pm PhD Candidate, Université Paris VII-Diderot, Centre d'études en sciences sociales sur les mondes africains, américains et asiatiques (CESSMA), France. E-mail: ecem.hasircioglu@etu.univ-parisdiderot.fr and ecem.hasircioglu@gmail.com.

${ }^{¥}$ PhD Candidate, Ecole Normale Supérieure de Paris-Saclay, Institut des Sciences sociales du politique (ISP), Teaching Assistant, Université de Nanterre, France. E-mail: gemreyildirim@gmail.com and galip-emre.yildirim@ens-paris- saclay.fr. 
motivation was and why that district became a "multiethnic" neighbourhood for various social groups. As the immigration phenomenon extends worldwide, it not only concerns the economic or political contexts of the countries, but also the cultural and social dynamics of immigration. The Europe's immigration policies, which firstly encouraged the "Gastarbeiter" phenomenon and then tried to stop it, highlighted the 2021th century immigration flows. Abdelmalek Sayad, in his famous work entitled "La double absence: Des Illusions de l'émigré aux souffrances de l'immigré" emphasized that the people who emigrate from one country to another bring their own customs, habits, way of life, way of thinking and also the political and economic structures of their own space ${ }^{1}$.

"To that extent, to immigrate means to immigrate together with one's history (immigration itself being an integral part of that history), with one's traditions, ways of living, feeling, acting, thinking, with one's language, one's religion and all the other social, political, mental structures of one's society (...). ${ }^{2}$ "

The immigration phenomenon, which first encouraged "guest workers" from decolonized countries or any others like Turkey, has experienced some changes over time. If we draw a quick scheme of Turkey's example: after the guest workers treatment, a second immigration wave raised through mostly Kurdish people in 1980, and as we see, in years, the Turkish immigration in France has evolved, from economic to political reasons. After 1980, during 1990 and 2000, the political-oriented migratory phenomenon continued but this type of immigration was always linked to the economic integration. Therefore, it can be said that the Turkish immigration in France gradually became more complex than it was. While the political-oriented immigration was a very significant matter for Turkey, citizens from any other countries that have been through multiple crises became immigrant actors in France too. So that, political issues, wars, discrimination against minorities etc. increased the "refugee" migration, which turned the migratory phenomenon into a whole new process. While the migration is at the center of the current debates because of the "refugee crisis" due to wars or political crises in various countries, the labor immigration and the cultural radiance continue. France is one of the countries that embrace those multiple types of immigration flows from all over the world as Michael Alexander said: "France became the premier country of immigration in Europe in the nineteenth century. Immigrants

\footnotetext{
${ }^{1}$ Abdelmalek SAYAD, La double absence: Des Illusions de l'émigré aux souffrances de l'immigré, 1999, Editions du Seuil. The suffering of the immigrant /Abdelmalek Sayad; preface by Pierre Bourdieu; translated by David Macey, 2004, Polity Press.

2 lbid., p.3.
}

Copyright @ 2018 BORDER CROSSING @ Transnational Press London 
from neighbouring countries were followed by newcomers from overseas colonies. In the postwar period, national policies facilitated movement into the country to fill the demographic deficit and meet manpower demand, resulting in large-scale labour immigration, especially from Portugal and Algeria"'.

This paper represents the stories of the ones who emigrated from Turkey to Paris, France and focuses on two parts. The first one is mostly our observation on the street and discusses representations of the main and side streets of the Faubourg. In that part, we try to understand the physical, economic, social and political structures of that area and the people of Turkish origin who run their business in the same neighbourhood. In short, our main question in the first part is why and how this place became a common area for immigrant and what part Turkish people play in the economic and socio-political representation of the Faubourg. In the second part, we try to discuss the migration policies of France and Turkey and the stories of our interviewees. In short, our main question in that part is how and under what circumstances some people of Turkish origin came to Paris, to the $10^{\text {th }}$ arrondissement more specifically, what kind of separation they have been through, and which image they have of their immigration and of Turkey. In that purpose, in this paper, after our field study, we reached the conclusion that they were three types of migration, which are labor migration, political refugee migration and cultural radiance. We studied the lives of the people who came from Turkey and settled down in the 10th arrondissement for very different reasons, and we questioned why that district matters to understand the migratory phenomenon of Turkish immigrants.

\section{Literature review}

As one of the main subjects of social sciences, there are obviously many studies on immigration. In order to draw a theoretical framework, we think that it is necessary to make a quick literature review about Turkish migration in Europe, particularly in France.

Riva Kastoryano studied the question of identity and the presence of people of Turkish origin in France and in Germany ${ }^{4}$. Stephane de Tapia did

\footnotetext{
${ }^{3}$ Michael ALEXANDER, Cities and Labour Migration: Comparing Policy Responses in Amsterdam, Paris, Rome and Tel Aviv, 2007, Aldershot: Ashgate, p.118

${ }^{4}$ Riva KASTORYANO, La présence turque en France. In: Hommes et Migrations, n¹172-1173, Janvier-février 1994. Minorités au Proche-Orient, sous la direction de Rochdy Alili et Paul Balta. pp. 7178.
}

DOI : https://doi.org/10.3406/homig.1994.2149 
many studies ${ }^{5}$ on Turks' social and economic integration ${ }^{6}$, on the transformation of the Turkish migration and discussed the Turkish diaspora ${ }^{7}$. Ayhan Kaya, Ferhat Kentel's $s^{8}$ and M. Murat Erdoğan's ${ }^{9}$ researches are very important researches including statistical results and analyzes. Those researches are about the multiple dimensions of Turkish migration in Europe, from political engagement to economic integration. Furthermore, Entegrasyonun Ötesinde: Türkiye'den Fransa'ya Göç ve Göçmenlik Halleri ${ }^{10}$ is another important resource to understand the Turkish migration in France. In that collective book, researchers, sociologists, anthropologists and journalists have studied that phenomenon, and some precious studies have been translated into Turkish. Moreover, Michael Alexander's Cities and Labour Immigration Comparing Policy Responses in Amsterdam, Paris, Rome and Tel Aviv ${ }^{11}$ is an important source in order to draw a comparative perspective about labor immigration cities. In this book, the Turkish migration is not the main focus but this study is very useful for understanding the conditions and policies of Paris.

On the other hand, there are some specific issues of scientific journals for Turkish migration in France, like CEMOTI ${ }^{12}$ and Hommes et Migration ${ }^{13}$

Riva KASTORYANO, "Etre Turc en France et en Allemagne », Cahiers d'études sur la Méditerranée orientale et le monde turco-iranien [Online], 13 | 1992, Online since 30 March 2004, connection on 02 October 2018. URL : http://journals.openedition.org/cemoti/351

${ }^{5}$ Stéphane de TAPIA, « Permanences et mutations de l'immigration turque en France ", Hommes \& migrations [Online], 1280 | 2009, Online since 29 May 2013, connection on 02 October 2018. URL: http://journals.openedition.org/hommesmigrations/286 ; DOI : 10.4000/hommesmigrations.286

6 Stéphane de TAPIA « Les entreprises turques d’Europe : intégration socio-économique de l'immigration et expansion économique ", Méditerranée [En ligne], 106 | 2006, mis en ligne le 21 octobre 2008, consulté le 01 octobre 2016, URL : http://journals.openedition.org/mediterranee/448 ; DOI : 10.4000/mediterranee.448

${ }^{7}$ Stéphane de TAPIA, Migrations turques en Europe. Définition dynamique d'un champ migratoire : circulation et diasporas. In: CEMOTI, $\mathrm{n}^{\circ} 18,1994$. Le Tadjikistan existe-t-il? Destins politiques d'une nation imparfaite, sous la direction de Stéphane A. Dudoignon et Guissow Jahangiri. pp. 233-262. DOI : https://doi.org/10.3406/cemot.1994.1113 www.persee.fr/doc/cemot_0764-9878_1994_num_18_ 1_1113

${ }^{8}$ Ayhan KAYA, Ferhat KENTEL, Euro-Turks: A Bridge or a Breach between Turkey and the European Union? A Comparative Study of French-Turks and German-Turks, CEPS EU-Turkey Working Paper 14, January 2005. http://aei.pitt.edu/6771/1/1189_14.pdf, last accessed 02.10.2018.

9 M. Murat ERDOĞAN, “Avrupa'da Türkiye Kökenli Göçmenler ve 'Euro-Turks-Barometre' Araştırmaları", Göç Araştırmaları Dergisi, Cilt: 1, Sayı: 1, Ocak- Haziran 2015, pp. 108-148

10 Didem DANIŞ, Verda IRTiŞ, Entegrasyonun Ötesinde: Türkiye'den Fransa'ya Göç ve Göçmenlik Halleri, İstanbul Bilgi Üniversitesi Yayınları, 2008

${ }^{11}$ Op.Cit. ALEXANDER

12 CEMOTI, $\mathrm{n}^{\circ} 13,1992$. L'immigration turque en France et en Allemagne. www.persee.fr/issue/cemot_0764-9878_1992_num_13_1

13 Hommes et Migrations, $\mathrm{n}^{\circ} 121 \overline{2}$, Mars-avril 1998. Immigrés de Turquie. www.persee.fr/ issue/homig_1142-852x_1998_num_1212_1 
These two scientific journals gave a special place to the Turkish immigration. For this rapid panorama of literature review, it is necessary to precise that we also read about anthropology and sociology of food. Strasbourg St. Denis is famous for its numerous Turkish/Kurdish restaurants, and "döner kebab" is the most common food in that area. For that reason, it was important to understand why döner kebab is never just a kebab for a defined social group. Some articles lead us to think about Turkish cuisine in Europe and its side effects like kinship, ethnic marketing, halal productions or else: From ethnic minority niche to assimilation: Turkish restaurants in Brussels ${ }^{14}$; Transnational Döner Kebab taking over the UK15; and Migration et Alimentation ${ }^{16}$. Finally, some particular researchers who focused on the 10th arrondissement of Paris are the ones that encouraged us to study the Faubourg St. Denis: Bernard Dinh ${ }^{17}$, Gaye Petek and Marie Poinsot ${ }^{18}$, Mustafa Poyraz ${ }^{19}$ and Kenan Öztürk's ${ }^{20}$ studies on 10th arrondissement and its business area were very precious examples for us.

\section{Beyond the gate: the Faubourg Saint Denis}

The Porte de Saint-Denis is an open gate to the Faubourg St. Denis Street (in French: Rue du Faubourg St. Denis), which is most famous street of the Strasbourg St. Denis area. When visitors arrive, they are welcome by Turkish/Kurdish restaurants and a Turkish supermarket. During the day, the main and side streets are crowded and the restaurants serve from late morning to the evening. The restaurants have Turkish names as Bernard Dinh mentioned ${ }^{21}$ and signs entitled "Spécialité Turque-Kurde". From the entrance to the first side street, visitors can easily see the "Turkish/Kurdish"

Hommes et Migration, $n^{\circ} 1280,2009$. Les Turcs en France : quels ancrages ? http://www.hommeset-migrations.fr/index.php?/numeros/5561-les-turcs-en-france-quels-ancrages

${ }^{14}$ Christian KESTELOOT and Pascale MISTIAEN "From ethnic minority niche to assimilation: Turkish restaurants in Brussels", Area, 1997, 29.4, pp.325-334

15 İbrahim SiRKECI, "Transnational Döner Kebab taking over the UK", Transnational Marketing Journal, Volume:4, No: 2, 2016, pp. $143-158$

${ }^{16}$ Manuel CALVO, "Migration et alimentation", Information sur les sciences sociales (SAGE, Londres et Beverly Hills), 21, 3, (1982), pp.383-446, https://doi.org/10.1177/053901882021003003.

17 Bernard DINH, "Un terrain marchand à l'épreuve de la diversité culturelle », Hommes \& migrations [Online], 1280 | 2009, Online since 29 May 2013, connection on 02 October 2018. URL: http://journals.openedition.org/hommesmigrations/315; DOI : 10.4000/hommesmigrations.315

${ }_{18}$ Gaye PETEK et Marie POINSOT, "La population turque dans le 10e arrondissement de Paris », Hommes et migrations [En ligne], 1312 | 2015, mis en ligne le 31 mai 2016, consulté le 02 juin 2016. URL : http://hommesmigrations.revues.org/3512

19 Mustafa POYRAZ, "Turcs et Indiens du faubourg Saint-Denis: Un espace commun en construction", Hommes \& Migrations n ${ }^{\circ} 1268-1269,2007$. DOI : https://doi.org/10.3406/homig.2007.4635

20 Kenan ÖZTÜRK, « Les Turcs dans la confection à Paris. Un aspect du paysage parisien des ateliers de couture » In: Hommes et Migrations, $n^{\circ} 1116$, novembre1988.pp.21-28. DOI : https://doi.org/10.3406/homig.1988.1223

${ }^{21}$ Op.Cit. DINH, p.109 
domination. From the first side street to the end of the street, the "IndoPakistanis" and "Asian/Chinese" visibility is obvious. There are also some French cafés and stores too. The Faubourg St. Denis is an area with multiple dimensions of economic and social integration. In other sense, in this "multiethnic" world where the Turks, the Kurds, the Arabs, the Indians, the Pakistanis live together and run their business, the diversity of the forms of their economic integration is a great part of that public space. In the Strasbourg St. Denis area, there are also very common side streets like the Rue d'Enghien, the Rue de Metz, and the Rue de Petites Ecuries where you can find Turkish restaurants and all sorts of shops.

In the late 1960's, as a first step of the Turkish immigration to France, previous studies have discussed the installation of Turks in $10^{\text {th }}$ arrondissement. That installation had a relative impact on the dressmaking sector ${ }^{22}$ and some of our interviewees who worked as dressmakers in their first years confirmed that situation. The Sentier area, very close to Faubourg St. Denis, was home to that dressmaking sector. Rémi Féraud, mayor of the $10^{\text {th }}$ arrondissement of Paris between 2008-2017 had a similar opinion about the impact of the dressmaking sector for the first settlement of Turks in his interview realized by Gaye Petek and Marie Poinsot for Hommes et Migration $^{23}$. The installation started with job opportunities for Turkish workers in the 1960's and continued in the 1980's and 1990's with Kurdish groups who emigrated from Turkey due to political conflicts. After the 2000 's, low-intensity migration flows still direct the people to that street, at least for their early "migrant" life.

Bernard Dinh, who studied the $10^{\text {th }}$ arrondissement, draws a very useful street scheme in order to categorize the visibility and activity of the different ethnic groups ${ }^{24}$. Dinh's scheme is a visual version of the presence and the domination of different ethnic groups. It can be said that the "Turks/Kurds" place at the entrance of the street, then the "IndoPakistanis" and the "Chinese" at the end of the street. In fact, the Turkish/Kurdish groups are obviously dispersed in different streets like the ones we mentioned before, but the "quartier turc" is valid for the first entrance of the street. Consequently, it is difficult to call that entire area a Turkish neighbourhood only. Moreover, the Asian origin groups are present in multiple sectors. There are some dress shops, women/men hairdressers, "traditional" food markets and telecommunication stores in their "ethnic"

22Op.Cit. POYRAZ, p.111; Op.Cit.ÖZTÜRK, p.23

${ }^{23}$ Op.Cit. PETEK, POINSOT, p.114

${ }^{24}$ Op.Cit. DINH, sondage 2007-2008, p.111

Copyright @ 2018 BORDER CROSSING @ Transnational Press London 
businesses. Mostly they are gathered in a famous passage of the street, called "Passage Brady" that turned into a "Little India". It can be said that those names like "Turkish neighbourhood" or "Little India" are only attributed by the residents and the visitors of the Faubourg St. Denis.

We think that there are two main representations in the $10^{\text {th }}$ arrondissement of Paris. We divide those representations in two categories: economic representations and socio-political representations. Many types of economic activities could define the economic representation, while the socio-political one is much more apparent through political or social movements.

\section{The economic representation of the street}

On the street of the Faubourg St. Denis and around, the most visible economic activity is the restaurant services. For the Turkish ones, döner kebab restaurants or fast-food kiosk control the market. Here, that kind of economic investment is a symbol of self-employment and related to network-mediated migration for the immigrants who live there. Christian Kesteloot and Pascale Mistiaen mentioned the "Hotelling effect" in order to describe the concentration on the same economic activity in the same economic area ${ }^{25}$. Those döner kebap restaurants can be considered as an adaptation to the economic area. The Turkish/Kurdish restaurants placed side by side are the indicator of the same tendency to the economic integration. The economic integration, which is much more visible in restaurant services, and especially with the döner kebab, is not only a phenomenon in France or Germany, it is also visible in the Netherlands, in the UK, in Belgium or in Finland. These local businesses are examples of social integration ${ }^{26}$ as well as social networks between immigrants. These networks are diverse. For example, during the interviews we found out that family members are working together, like husband-wife, father- sons or near relatives, friends, friends of friends, and other residents ${ }^{27}$. Therefore, it can be said that the social networks, family and "ethnic ties" play a huge part in the economic integration in the shops we conducted our fieldwork, as Ram et al. also discussed that phenomenon in their article ${ }^{28}$.

${ }^{25}$ Op.Cit. KESTELOOT, MISTIAEN, p.327

${ }^{26}$ Op.Cit. de TAPIA, p.105

27 Prodromos Ioannou PANAYIOTOPOULOS, "Turkish immigrant entrepreneurs in the European Union: a political-institutional approach", International Journal of Entrepreneurial Behavior \& Research, Vol. 14, 2008, Iss 6 p.402, https://doi.org/10.1108/13552550810910979

${ }^{28}$ Monder RAM, Balihar SANGHERA, Tahir ABBAS, Gerald BARLOW \& Trevor JONES (2000) Ethnic minority business in comparative perspective: The case of the independent restaurant sector, Journal of Ethnic and Migration Studies, 26:3, 495-510, DOI: 10.1080/713680492. 
We have to note that these local restaurants and supermarkets serve from the morning until late at night, so it can be said that the workers and owners' working rhythm is highly intense.

The long-hour working rhythm and the high temperature in the restaurant kitchen show that the labor-intensive work is part of their "migrant" life. In the light of those facts, it could be said that for the people of $10^{\text {th }}$ arrondissement, in the Faubourg St. Denis and in other streets, are mostly working in a business area. Therefore, living in the banlieue is a frequent phenomenon among the immigrants ${ }^{29}$. The majorities of our interviewees also live in the banlieue and come to Paris for work only, at least six days of the week.

According to our observation and visits, it is also possible to describe local Turkish/Kurdish restaurants. Those restaurants are the majority in the streets, and their menus and prices are more or less similar. In those restaurants, there are some Turkish figures and décor objects like a picture of the Maiden Tower or a photograph of the Blue Mosque. While each of those places have a different atmosphere, there are some similar characteristics. First, these restaurants serve both Turkish cuisine and Turkish take-away food (döner kebab or else). In addition, in those places, the clients are very diverse; not only Turkish or Kurdish people, but also anyone who passes the restaurants could be a customer of any of these places. There, the presence of "ethnic" food sector influences eating habits of not only people of Turkish origin, but also French people, or people of other origins. Even though the language skills of the workers or the owners are not very qualified, they speak first in French with their clients. The workers are mostly middle-aged men, and they speak in Turkish to each other. Because of the long-hour working, the socialization among them is not very common but we observed that they know each other, sometimes come over other restaurants. When we asked their relationship with other ethnic groups like Indians or Pakistanis, they said that they had no problem with them but in fact, they do not communicate often.

Besides, it is necessary to mention that the economic representation is not all about the food sector. Even though this sector has many subcategories like halal butcher shops as a great part of the Muslim immigration and meat consumption attitude under the auspices of religion; there are also Turkish-oriented markets, dairy products (Turkish cheese for example), even bread (Ramadan pita or loaf of bread) and patisserie products (simit or bun), barbershops, jewelers (gold-oriented), bookstores,

${ }^{29}$ Op.Cit. DINH, p.115 ; Op.Cit. ALEXANDER, p.115

Copyright@ 2018 BORDER CROSSING @ Transnational Press London 
and tourism agencies that are part of that economic representation. Each of those has a direct link to Turkey. Therefore, we thought that the economic representation is one of the main subjects of that public space.

\section{The socio-political representation of the street}

The $10^{\text {th }}$ arrondissement territory, as Bernard Dinh and others explain, is a business area that constitutes a "multiethnic" public space. Beyond that business area, the Faubourg St. Denis Street and the streets around are also sociopolitical areas with plenty of meetings, events, political posters, banners and associations. As we mentioned before, we classified two main representations of the $10^{\text {th }}$ arrondissement. Within the framework of this study, the socio- political representation of the Faubourg St. Denis is not only the political engagement of the interviewees but also the political standing of the street itself. Here, we prefer to use the phrase "appropriation of the territory" as Riva Kastoryona ${ }^{30}$ and Patrick Simon ${ }^{31}$ coined it in their studies. Kastoryano describes that kind of appropriation with the visibility of economic activities, social networks, as well as visual images like posters and graffiti on the walls. We thought that this appropriation of that public space by Turkish/Kurdish migrant actors is made possible by a "sense of belonging", at a political or economic level. Consequently, this appropriation term also applies when we speak of any other ethnic communities who settled down in that area. The IndoPakistanis or Chinese immigrants also have a sense of belonging towards that street as Dinh, Öztürk and Poyraz explain in their articles. Therefore, the "Petite Turquie", "Petite Istanbul" or "Little India" terms are actually attributions and only made real because the immigrants accept them. We thought that those attributions are also part of the political standing of the street itself. For instance, a special event called "La P'tite Istanbul en fête" takes place in May every year at the cross streets of Faubourg St. Denis and Rue de Metz. The "quartier turc" term is attributed to that street and legalized in a way by this annual event. It can be seen that the walls of the main and side streets became the tools to show the political engagement. The critics against the government and the democratic issues, the slogans against discrimination, the $1^{\text {st }}$ May posters or the call for voting "No" at the last referendum in Turkey show the political dynamism in the street.

${ }^{30}$ Op.Cit. KASTORYANO, p. 73.

31 Patrick SIMON, "Les quartiers d'immigration : " ports de première entrée» ou espaces de sédentarisation ? L'exemple de Belleville." In: Espace, populations, sociétés, 1993-2. La population française dans son espace - The French population within its own space. P.379. DOI : https://doi.org/10.3406/espos.1993.1598. 
However, regarding our interviewees' political engagement, we have to admit that the majority of them are not much interested in actively political engagement.

\section{Research method}

Regarding its method, this paper is based on a qualitative research method. To carry out this study, we have interviewed the owners and the workers of various stores and shops in the 10th arrondissement. In addition to this, since last year we occasionally visited the area, went shopping, met people, and ate in their restaurants. To better reflect the atmosphere of Strasbourg St. Denis, we took photographs of the shops, passages, restaurants, and cultural, political banners and posters on the walls. The main reason why the study leans on the qualitative method is our purpose, which is to represent the in-depth stories of people of Turkish origin. Why and how did they settle down in that neighborhood? How and why did they decide to emigrate? According to our three-type immigration scheme, which type corresponds to their immigration? How did they start their business? Why do people call this area Little Turkey? How do they run their business with their family members? As an economic and social area, why is the Faubourg St. Denis important to understand a social group? Finally, how do they see Turkey and the "return myth"? Those questions below are the ones that lead us to understand Turkish people of the $10^{\text {th }}$ arrondissement and analyze the link between a public space and immigration. In other words, this paper aims to understand the immigration phenomenon in the light of life conditions, private issues, political matters, and more importantly, life changes. Therefore, even though we use some statistical data, our main results lean on the responses of the fieldwork actors to our semi-directive questions. For that reasons, we would insist on "singularity" of their immigration experiences. In addition to that, as a very common public space, the Faubourg St. Denis itself was our fieldwork and the people we met are the actors of that fieldwork.

Our interviewees are from food sector, supermarket/grocery store, and bookstore and service sector. In order to make it easier to identify our interviewees, we nicknamed them as follow: Interviewee 1, 2, 3, 4, 5, 6, 7. We briefly introduce our other interviewees: Interviewee 1 has lived in Paris for 18 years and works with her husband in food sector. She came here via family reunification. Interviewee 2 has lived here for 38 years and came here for studying but could not finish. Now he works in food sector with his second wife but before he worked as a dressmaking worker in the Sentier, and then got a plumber certificate and still works in installation. 
Interviewee 3 has lived in Paris for 3 years and came as a political refugee due to political issues in Turkey. He works in food sector too since he came here, and is married to a Turk. He is engaged in some workers' association. From the first moment to the end of the interview, he only spoke about political matters. His political discourses are generally about current crises and democratic issues, the Kurdish issue, the Gezi protest among others. Therefore, his political engagement can be considered as linked to the mainstream political phases.

Interviewee 4 has been living here for 29 years and came as a political refugee. He is married to a Turk too. He worked as a waiter in some Turkish restaurants. Now he manages a market/grocery store for 17 years with his son. Now, 29 years after, he only mentioned the positive side effects of the "peace process" in Turkey and nothing more.

Interviewee 5 has lived here for 27 years and came as a political refugee. He is married to a Turkish woman from the second-generation immigrants. He has run his business for 5 years now in bookstore. We could say that he barely talked about his political engagement; the only thing he said was that the religion and the politics should not be mixed in the political scene.

Interviewee 6 has been living here for almost 20 years and came here after education in a French school in İstanbul. Interviewee 6 came here to start a business in service sector and built a family with a French.

Interviewee 7 has lived here for almost 30 years and came here to study. Nevertheless, this person could not finish higher education and started to work in service sector. Now interviewee 7 built a family with a French person too.

As we observed, contrary to the Kurdish movement, the nationalist/religious movement in the Faubourg St. Denis is less visible. There is a bond between the local businesses whose owners or workers are engaged in the nationalist/religious movement but in the streets, there is no dominant presence of their own symbolic posters.

Apart from our interviews, we took part in a special event in one of the stores. In that event, young people and adults came together for conversation, music, and reading some poems that were written by one of the participants. During that event, the owner of the store offered tea and showed us a couple photograph albums in which we could see another event, in which he offered roses to the people who came. We assumed that this type of gathering has a much more socio-cultural tendency than a political one. Therefore, until we asked about their political engagement, their discourses were not politicized at all. During that gathering, we had the chance to meet three young Turkish people and asked their relationship 
to that street. All of them live in another arrondissement and come by to that area to visit that store and participate in some of their events.

The interviews were only made with people of Turkish origin, however we also asked about their relationship with the other ethnic groups, like Indians, Pakistanis, etc. Nevertheless, we have to admit that when we conducted our fieldwork, some workers and owners have refused to answer our questions, so our study is not an entire analysis of the 10th arrondissement as it is limited to our observations and interviews. It is obvious that each person who emigrated from Turkey have different baggage. While they have similar backgrounds and immigration stories, they have unique experiences in their own life. In this respect, we have to underline that this study is meaningful in our research field, which is limited to the interviewees' discourses. This paper, which could be developed thanks to previous researches, aims to be a part of further immigration studies.

\section{The stories behind the immigration: Policies, changes, experiences}

When we were conducting the interviews with the Turkish immigrants in the $10^{\text {th }}$ arrondissement of Paris, we realized that the immigrants who came from Turkey could be regrouped in three general categories. These categories also explain their migration reasons. Those three general motives are economic, cultural (educational) and political reasons. The three elements produce another two transversal migration practices that change the way research is conducted. It can be seen that the economic reasons are subsequently associated to the familial reunification that can be considered as another reason for migrating, and to the political orientation, which is the prominent factor of the refugees or asylum seekers.

If we follow the chronology of the migration history from Turkey to France, it all started for economic reasons. The economic reasons are the ordinary factor for migrating. That is why the migration studies focus more generally on the developed countries. The European countries, the USA and the UK are considered mostly as the principal destination for immigrants. Here it could be underlined that there are historical, economic and presenttime factors. Before a country hosts a person, this person has chosen to live in that country. On the one hand, immigrants come to France because of its economic potential. Historically, France is an early industrialized country. That is why France is one of the principal destinations for the migrant actors. On the other hand, historical reasons refer to the colonization past of France. By ending this structure, France started to host the people who 
come from the colonized areas. These reasons are associated to the economic criteria in France.

If these countries are described as the host areas for immigrants, the immigration phenomenon has to be analyzed through two variables: the inflow factor and the outflow factor of the migrants. The economic projects of the people have a key role in determining their position, which depends on the stability. It is noteworthy that this stability refers to the economic situation of the migrants. Therefore, it can be said that achieving economic goals is very important for immigrants. This is why the stability and the economic project of the migrant's situation are one of the most significant elements for redefining a relationship legally between immigrants and the State. The legality of immigrants determines also their personal life in the host country. For example, migrants who entry a country for economic or professional reasons needs to regularize their status by having a residence permit. It inaugurates the second type of migration elements, which are formalized by the international agreements that is the family reunification.

Table 1.

\begin{tabular}{|l|l|l|}
\cline { 2 - 3 } \multicolumn{1}{l|}{} & $\begin{array}{l}\text { The workforce treaties with Turkey of the European } \\
\text { Countries }\end{array}$ & \\
\hline Countries & Dates & Place Signed \\
\hline Germany & 30 October 1961 & Bad Godesberg \\
\hline Austria & 15 May 1965 & Vienna \\
\hline Belgium & 16 Jul 1964 & Brussels \\
\hline Netherlands & 19 August 1964 & Lahey \\
\hline France & 8 Avril 1965 & Ankara \\
\hline Sweden & 10 March 1967 & Stockholm \\
\hline
\end{tabular}

Source: Ministry of Labor and Social Security of Turkey https://www.csgb.gov.tr/ media/2075/isgucuanlasmalari.pdf

However, the immigrants from Turkey make an exception if these historical and economic reasons are taken into consideration, because Turkey is not a colonized country of France. At this point, we describe the migration reasons of those who are coming to France around three elements. The economy has a key role in the host country of France for the Turks. The economic migration phenomenon was legalized in the State convention between France and Turkey in 1965. At the beginning, through

32 T.C. Çalışma ve Sosyal Güvenlik Bakanlığı, Uluslararası İşgücü Anlaşmaları, https://www.csgb.gov.tr/media/2075/isgucuanlasmalari.pdf , consulted in 15.08.2017 38 Ministère de I'Intérieur, Direction Générale des étrangers en France. https://www.immigration.interieur.gouv.fr/ Immigration/ L-admission-au-sejour-Les-titres-de-sejour-statistiques , publié 8 Juillet 2016 
the agreement between the two countries for guest workers, the status of the migrants of Turkish origin was protected under this agreement.

The migration as a transversal subject could be also observed as a State policy. Since 2009, France has been hosting legally more than 200,000 persons as migrants who arrived in the country as the data obtained shows below. ${ }^{33}$

Table 2.

\begin{tabular}{|r|r|r|r|r|r|r|r|r|}
\hline $\begin{array}{r}\text { Admission } \\
\text { criteria }\end{array}$ & 2009 & 2010 & 2011 & 2012 & 2013 & 2014 & $\begin{array}{r}2015 \\
\text { Provisional }\end{array}$ & $\begin{array}{r}\text { Evolution } \\
2014\end{array}$ \\
\hline Economic & 20185 & 18280 & 17834 & 16013 & 17800 & 19054 & 20601 & $8,1 \%$ \\
\hline Familial & 85715 & 83182 & 81172 & 87170 & 93714 & 92326 & 89488 & $-3,1 \%$ \\
\hline Student & 58586 & 65281 & 64928 & 58857 & 62815 & 64996 & 69782 & $7,4 \%$ \\
\hline Divers & 11343 & 11572 & 11633 & 12624 & 13148 & 13742 & 13766 & $0,2 \%$ \\
\hline Humanitarian & 18581 & 18220 & 17487 & 18456 & 17916 & 20822 & 21583 & $3,7 \%$ \\
\hline Total & 194410 & 196535 & 193054 & 193120 & 205393 & 210940 & 215220 & $2 \%$ \\
\hline
\end{tabular}

Source: Ministère de l'Intérieur, Direction Générale des étrangers en France, AGDREF/DSED

According to the French Interior Ministry, there are five general criteria to become a legal immigrant or to have a titre de séjour ${ }^{34}$. These five criteria are determined as the reason for obtaining the permission of residence. They can be economic, familial, educational, humanitarian and diverse. The schema above shows us that at the beginning, the European countries, especially Germany, demanded that the Turkish people came to Europe as "guest workers". The European construction after the WWII has a key role for the acceptance of the migrants into the European economic area. Nevertheless, these policies, which concerned the hosting workforce migrants, are abandoned by the same countries nowadays. The reason behind that decision was at first the "saturation" of the workforce and then it turned into a political crisis because of the "illegal" residence and the threats it posed to the workforce. These polemics push the government to reinforce their borders against the migrants. Now, there is also a fear towards "terrorism" and it is associated with the migration and asylum demands. Therefore, it can be argued that if the "migrant" and the "migration" terms became a stigma. Consequently, the migration phenomena could be analyzed through the State policy, as a component that determines the relations among the people and the governments. In

33 Ministère de I'Intérieur, Direction Générale des étrangers en France. https://www.immigration.interieur.gouv.fr/Immigration/L-admission-au-sejour-Les-titres-de-sejourstatistiques, publié 8 Juillet 2016

${ }^{34}$ Ibid.

Copyright @ 2018 BORDER CROSSING @ Transnational Press London 
juridical terms, immigrants have a legal position that links the statuses granted by State to the immigrants or refugees.

Moreover, this is a political position taken directly by the refugee against the politics of the origin country. At this point, it can be argued that being a refugee constructs a "radical" individual action because of the administrative status that the refugee has. This behavior consists of many interdependent factors as a whole. The consequences of such an individual action could be observed through the society of emigration and also the society of immigration. Some of our interviewees who are refugees prove it with their speeches, which are highly politicized. The words used by the other interviewees who are immigrants for economic reasons have apparently less political motivations. However, all of these three categories described above have naturally interdependence with the host society. This phenomenon is underlined by Abdelmalek Sayad: "Any attempt to construct immigration as a true object of science must, finally, be a social history of the reciprocal relations between the societies, of the societies of the emigration and the society of the immigration, of relations between emigrants and immigrants, and of relations between each of those two societies 35 ". This observation about the migrants' social psychology draws the conclusion that the complexity of the migration phenomenon could be seen through the spectrum of the individual projects, the societal reflexes of the societies and the State policies that are produced. This is why our research will be based on these axes and on the statistical data obtained from official sources like the Organisation for Economic Co-operation and Development (OECD), the European Union's institution and French ministries' databases. It is necessary to put forward a valid interpretation of the results and compare the outcomes with what we have studied during our sociological observation at the $10^{\text {th }}$ arrondissement.

The political structure of Turkey directly influences the refugee demands of those who want to come to France. After the 1980 coup d'état in Turkey, many people demanded to be refugee in the European countries such as Belgium, Germany, France, and the Netherlands. Even if the domestic politics were more stable than in the 1980s, the refugee demands continued, especially in France. Between 1993 and 2012, the people who have the Turkish citizenship are the most refugee demanders among the 27 nationalities in France ${ }^{36}$. According the L'Office français de protection des réfugiés et apatrides (OFPRA) report published in 2012, more than 50.000 Turks applied to have a refugee status in France. Among them,

\footnotetext{
${ }^{35}$ Op.Cit. SAYAD, p. 2

36 OFPRA, 1952-2012/60 Ans à l'écoute du monte, Rapport d'activité, 2012, p.58
} 
approximately 12.000 could have obtained the political protection rights ${ }^{37}$. The report let us know that the principal reason for these refugee applications is mainly the fact of being a Kurdistan Worker's Party (PKK) supporter, or a member of the Kurdish political parties or organizations ${ }^{38}$. This directly regards the main political issue of Turkey that affects other countries in Europe like Germany and France. Nevertheless, the political issues in Turkey gave birth to a second type of migration: political refugees.

The third reason is based on the cultural, scientific and educational policy of France that is called "cultural radiance". In Turkey, there are French high schools; one university which was founded by the Turkish and French governments, and some francophone departments in other universities. These educational flows allow Turkish students to take part of the Francophone cultural group. After their educational background in Turkey, these students have some possibilities to continue their academic formation in France with the scholarships provided by the French Government under the direction of Campus France. Meanwhile, the cultural radiance seems to be a new model of motivation for immigration for the Turkish youth.

Even if we have easily categorized these immigrants by considering their social, economic and political engagement in France, being a migrant for any reason has some behavioral effects on the immigrants' lives. We could focus on their particular migrant stories that are derived from their different goals. The micro-sociological approaches would be more applicable on this issue in order to understand the individual diversities among those three categories on what we try to describe. From our point of view, "the bottom-up" field research adapted to this migration study would be effective in order to obtain consequences that are more accurate. That would help us to construct a valuable argumentative method.

From this "bottom-up method", the migration could be analyzed through the spectrum of two general issues: the first one is that the immigration is an individual behavior that appears as the result of a personal decision. Here is the phenomenon that has psychological consequences on the behavior of migrants. During our interviews, the last question was addressing this issue with a simple question: what do you think of the idea of returning to Turkey? The answers of the interviewees to that question cannot be easily categorized. Interviewee 5 from bookstore, who has a strong religious orientation due to his refugee motive of migration to France, does not think about returning to Turkey. Even if his

${ }^{37} \mathrm{Ibid}$.

${ }^{38}$ Ibid p.28

Copyright @ 2018 BORDER CROSSING @ Transnational Press London 
wife is a French person of Turkish origin, he told us that he could not do it because of their family roots. However, interviewee 2 from food sector who has the same religious engagement and interviewee 3 who came to Paris with the refugee status, confirmed that they could easily return to Turkey on some conditions, like a moderate political structure or an individual economic situation. Nevertheless, this is a vague project for all of the interviewees.

The second issue is the "integration degrees" of our interviewees. The similarity or the differences about the idea of "returning" to the origin country are not derived from their integration degree within the host society. Here, we refer the "integration" term as a socio-economic integration of those who settled in that business area. The personal life of the migrant actors has a key role in this integration process. In general, there could be three different ways of seeing integration: "well-integrated", "semi-integrated", and "less-integrated" immigrants. The research field's results show us that there is a transversal position between the labor workers and the refugees from Turkey towards "semi-integrated" and "less-integrated issues", whereas the cultural radiance apparently provides a "well-integrated" life to the migrants. For example, interviewee 3 from food sector as a refugee represents a "less- integrated" position in the French society. His wife is also of Turkish origin, but she speaks French, while his language skills in French are not very well developed. He says, "I did not speak French before coming to Paris, now I know a little French, which helps me to do my job". Interviewee 2 from food sector who has the religious vocation informed us that he had no problem speaking French. Actually, his second wife is from Maghreb and they speak French to each other. Nevertheless, his integration position remains "semi-integrated", because his future plans are based on returning to Turkey. With his wife, they planned to move to Thrace in order to create a new life in that country.

The "well-integrated" position is still questionable. Could we describe a migrant's life as a well- integrated into the host society? This is a complex question for which it is hard to find a proper answer. Nonetheless, those who have a cultural background before coming to Paris are more able to integrate well into French society than the other two categories of migrants. Their French speaking and writing level is better in comparison than the one of the labor workers and the refugees, because unlike them, these migrants were already part of the francophone education system in Turkey. According to our fieldwork, after coming to France, they married mostly French men or women and their children have French names. Their marriage with a French person, their educational background, and their economic capacity also help them to acquire the French citizenship. This 
legal particularity reinforces their integration level into the French society. The language skills generally have a decisive effect on the French naturalization process.

This three-degree integration affects the relations among the host society and the migrant's social life. The consequences of a less-integrated position results in a phenomenon that is called "communitarianism". Here, the migrants use some mechanisms as the regulation of their migrant life. It could be argued that their political engagement and economic activities represent the main instruments to balance the social life and their "migrant" universe. The refugees, especially the youngest ones, have an ideological speech about the daily politics of Turkey even if they are not interested in the French political structure. The language skills they have and the economic area where they work in under the socialization with the other migrants from Turkey could be a prominent reason in their political interest. However, the labor migrants' behavior could be also explained by the "communitarianism": here, the difference among the labor workers and refugees is the political engagement level. The labor workers, such as the example of local restaurants, have a generally apolitical speech. Their migration project is based on the economic situation in France. This is why they are not interested in everyday politics. An interviewee concludes her migrant position in politics by saying that "I am the member of the bread party". She explains that she and her husband had to work their whole life in order to protect their economic acquisitions. However, she does not want to work hard for the rest of her life and wants to return to Turkey when she retires. It can be seen that their working rhythm could explain that the labor integration refers to a partial alienation. Serge Paugam describes this type of professional integration as a standard form of professional integration that corresponds to employees who are generally dissatisfied with their work but whose employment is not threatened ${ }^{39}$.

What distinguishes the less-integrated migrants and the semi-integrated ones is the "institutional communitarianism". A semi-integrated migrant who is a labor migrant or a refugee often gathers under an association within the religious or political engagement. The migrants' associations have an important role in the institutional plan of "communitarianism". The goal of the religious vocation organizations consists purely in protecting the national culture of the Turkish origin migrants, whereas the other associations in which the Kurdish/Alevi refugees are engaged are more politicized, mostly under the leftwing mobilization. The similarity of those

\footnotetext{
${ }^{39}$ Serge PAUGAM, Le salarié de la précarité : Les nouvelles formes de l'intégration professionnelle, Presses universitaires de France, coll. « Quadrige essais débats », 2007. 
two types of associations is that the migrants engage in the organizations in order to preserve their religious or political attitudes. It could be said that the associations are conceptually a regulation instrument of the migrants in their daily life. That phenomenon apparently reinforces the "communitarianism" issue in terms of integration level.

\section{Conclusion}

In that paper, we preferred to focus on a specific neighbourhood where migrants of Turkish origin settled down, especially for economic purposes. This paper represents a local study, which embraces multiple dynamics in economic, social or political representations. In that respect, our frequent visits, our friendly conversations with the shopkeepers, our interviews, and our visual witnessing constitute the methodological steps of that research.

We would emphasize the fact that beyond the Porte de Saint-Denis, there is a first business area that reflects many types of economic integration for the various social groups. Not only Turkish/Kurdish people but also Indo-Pakistanis, Chinese or African people settled down and now run their business; therefore, all of them turn that district into a "multiethnic" neighbourhood. In terms of Turkish immigration in France, we could say that whatever the migration reason is, the main purpose of their presence in the $10^{\text {th }}$ arrondissement is firstly economic. Following the food/restaurant sector and the textile industry, which helped to form a common area for immigrants, many other economic investments have been transferred the Faubourg streets. On the other hand, the Kurdish people have massively appropriated the street and its socio-political representation. On the contrary, nationalist/religious movements or sanctuaries are less visible, nearly hidden. Our interviewees are more engaged in the economic representation of the street, they work in the $10^{\text {th }}$ arrondissement after all. However, from time to time, they declared that they could become interested in social-political movements, which take place in the main and side streets. As we observed, the restaurant/food sector is a huge part of the economic integration but we think that it is necessary to study specifically the Turkish tourism agencies in order to understand that sector and its owners/workers' profile. That kind of study may not only enlighten an economic investment, but also a cultural radiance type of migration, according to our experiences. This study is now under development and will be our next paper.

There is also one last point that we want to underline about our interviewees: the return myth. The return myth, a "vague project", has been observed especially in the "semi-integration" model, which we think 
is the dominant pattern in our fieldwork. "Neither from here, nor from there" as a shield phrase of the interviewees reflects that the longer and the better the economic integration was, the more difficult it would be to decide to come back. Therefore, our interviewees 4, 5, 6, 7 declared that they could not easily face a return to Turkey after all these years, despite their nostalgia. However, interviewee 3 said that he could return to Turkey when the conditions are better.

The Turkish everyday politics partially affects the migrant life in France. The violence committed against to the one of the stores, and the critics of some of the interviewees against the conservative policy of the Turkish government are just some examples that we have seen. The speech of the interviewees is related to the political development of Turkey upon religious or ethnical issues. All of those phenomena have a historical background that we cannot study in this article.

In the light of those analyzes, we discussed how and why migrants of Turkish origin have gathered around the $10^{\text {th }}$ arrondissement and how they "built" that area in their own way. Shortly, the immigration stories, the State policies, the integration models, the economic integration, the political engagement, the network orientation, and the special events of the immigrants from a specific neighbourhood have been argued in that research, and a public space itself has been examined in detail.

\section{References}

Alexander, Michael (2007) Cities and Labour Migration: Comparing Policy Responses in Amsterdam, Paris, Rome and Tel Aviv. Aldershot: Ashgate.

Calvo, Manuel. "Migration et alimentation", Information sur les sciences sociales (SAGE, Londres et Beverly Hills), 21, 3, (1982), pp.383-446, https://doi.org/10.1177/053901882021003003.

CEMOTI, $n^{\circ} 13$, 1992. L'immigration turque en France et en Allemagne. www.persee.fr/ issue/cemot_0764-9878_1992_num_13_1

Danış, Didem, İrtiş, Verda, (2008) Entegrasyonun Ötesinde Türkiye'den Fransa'ya Göç ve Göçmenlik Halleri, İstanbul Bilgi Üniversitesi Yayınları

Dinh, Bernard "Un terrain marchand à l'épreuve de la diversité culturelle ", Hommes et migrations [En ligne], 1280 | 2009, mis en ligne le 29 mai 2013, consulté le 01 octobre 2016. URL : http://hommesmigrations.revues.org/315 ; DOI : 10.4000/hommesmigrations.315

Erdoğan, M. Murat, “Avrupa'da Türkiye Kökenli Göçmenler ve 'Euro-Turks-Barometre' Araştırmaları”, Göç Araştırmaları Dergisi, Cilt: 1, Sayı: 1, Ocak- Haziran 2015 • ss. 108-148

Hommes et Migrations, $\mathrm{n}^{\circ} 1212$, Mars-avril 1998. Immigrés de Turquie. www.persee.fr/ issue/homig_1142-852x_1998_num_1212_1

Hommes et Migration, $\mathrm{n}^{\circ} 1280,2009$. Les Turcs en France : quels ancrages ? http://www.hommeset-migrations.fr/index.php?/numeros/5561-les-turcs-en-france-quels-ancrages

Kastoryano, Riva. La présence turque en France. In: Hommes et Migrations, n¹172-1173, Janvierfévrier 1994. Minorités au Proche-Orient, sous la direction de Rochdy Alili et Paul Balta. pp. 71-78. DOI : https://doi.org/10.3406/homig.1994.2149 
Kastoryano, Riva. "Etre Turc en France et en Allemagne », Cahiers d'études sur la Méditerranée orientale et le monde turco-iranien [Online], 13 | 1992, Online since 30 March 2004, connection on 02 October 2018. URL : http://journals.openedition.org/cemoti/351

Kaya, Ayhan, Kentel, Ferhat (2005) Euro-Turks: A Bridge or a Breach between Turkey and the European Union? A Comparative Study of French-Turks and German-Turks, CEPS Publications, Centre for European Policy Studies, Brussels

Kesteloot, Christian, Mistiaen, Pascale, "From ethnic minority niche to assimilation: Turkish restaurants in Brussels", Area (1997) 29.4, 325-334

Ozturk Kenan. Les Turcs dans la confection à Paris. Un aspect du paysage parisien des ateliers de couture. In: Hommes et Migrations, n¹116, novembre 1988. pp. 21-28. DOI: doi.org/ 10.3406/homig.1988.1223.

Panayiotopoulos, Prodromos loannou (2008). "Turkish immigrant entrepreneurs in the European Union: a political-institutional approach", International Journal of Entrepreneurial Behavior \& Research, Vol. 14 Iss 6 pp. 395 - 413 Permanent link to this document: http://dx.doi.org/10.1108/13552550810910979

Paugam, Serge, Le salarié de la précarité : Les nouvelles formes de l'intégratıon professionnelle, Presses universitaires de France, coll. "Quadrige essais débats », 2007, 437 p., EAN : 9782130558460.

Petek, Gaye et Poinsot, Marie " La population turque dans le 10e arrondissement de Paris ", Hommes et migrations [En ligne], 1312 | 2015, mis en ligne le 31 mai 2016, consulté le 02 juin 2016. URL : http://hommesmigrations.revues.org/3512

Poyraz, Mustafa "Turcs et Indiens du faubourg Saint-Denis: Un espace commun en construction", Hommes \& Migrations n ${ }^{\circ}$ 1268-1269, 2007. DOI : https://doi.org/10.3406/homig.2007.4635

Ram, Monder, Sanghera, Balihar, Abbas, Tahir, Barlow, Gerald \& Jones, Trevor (2000) Ethnic minority business in comparative perspective: The case of the independent restaurant sector, Journal of Ethnic and Migration Studies, 26:3, 495-510, DOI:10.1080/713680492

Rapport: OFPRA, 1952-2012/60 Ans à l'écoute du monte, Rapport d'activité, 2012

Sayad, Abdelmalek (1999) La double absence: Des Illusions de l'émigré aux souffrances de I'immigré, 1999, Editions du Seuil. The Suffering of the Immigrant /Abdelmalek Sayad; preface by Pierre Bourdieu; translated by David Macey, Polity Press, 2004.

Simon, Patrick. "Les quartiers d'immigration : " ports de première entrée» ou espaces de sédentarisation ? L'exemple de Belleville." In: Espace, populations, sociétés, 1993-2. La population française dans son espace - The French population within its own space. pp. 379387; doi : 10.3406/espos.1993.1598.

Sirkeci, Ibrahim. 2016. "Transnational Döner Kebab taking over the UK", Transnational Marketing Journal, Volume: 4, No: 2, pp. $143-158$

De Tapia, Stéphane. "Permanences et mutations de l'immigration turque en France ", Hommes \& migrations [Online], 1280 | 2009, Online since 29 May 2013, connection on 02 October 2018. URL : http://journals.openedition.org/hommesmigrations/286 ; DOI : 10.4000/ hommesmigrations.286

De Tapia, Stéphane. "Les entreprises turques d’Europe : intégration socio-économique de I'immigration et expansion économique ", Méditerranée [En ligne], 106 | 2006, mis en ligne le 21 octobre 2008, consulté le 01 octobre 2016, URL: http://journals.openedition.org/ mediterranee/448; DOI : 10.4000/mediterranee.448

De Tapia, Stéphane. Migrations turques en Europe. Définition dynamique d'un champ migratoire : circulation et diasporas. In: CEMOTI, $n^{\circ} 18,1994$. Le Tadjikistan existe-t-il? Destins politiques d'une nation imparfaite, sous la direction de Stéphane A. Dudoignon et Guissow Jahangiri. pp. 233-262. DOI : https://doi.org/10.3406/cemot.1994.1113 www.persee.fr/doc/cemot_07649878_1994_num_18_1_1113

De Tapia, Stéphane. "Les entreprises turques d’Europe : intégration socio-économique de I'immigration et expansion économique ", Méditerranée [En ligne], 106 | 2006, mis en ligne le 21 octobre 2008, consulté le 01 octobre 2016. URL : http://mediterranee.revues.org/448 ; DOI : $10.4000 /$ mediterranee.448 


\section{Beyond the Porte de Saint-Denis}

\section{Statistical data}

Ministère de I'Intérieur, Direction Générale des étrangers en France https://www.immigration. interieur.gouv.fr/Immigration/L-admission-au-sejour-Les-titres-de- sejour-statistiques

T.C. Çalışma ve Sosyal Güvenlik Bakanlığı, Uluslararası İşgücü Anlaşmaları, https://www.csgb.gov.tr/ media/ 2075/isgucuanlasmalari.pdf , consulted in 15.08.2017 